\title{
Exploration of Genetic Variability of Bean (Phaseolus vulgaris L.) Landraces through ISSR Markers
}

\author{
By Margarita Gisela Peña-Ortega* \\ Luis Manuel Serrano-Covarrubias ${ }^{\dagger}$ \\ Juan Martínez-Solís
}

In this study, 30 bean landraces collected from three Mexican states, namely Puebla, Zacatecas and Oaxaca, were evaluated in order to estimate genetic diversity among them through their genomic fingerprints obtained from ISSR (Inter Simple Sequence Repeat) markers. Genetic variability of semi-domesticated bean populations is a valuable resource for plant breeding programs as a source of stress-tolerant genes that were lost during the selection process of commercial cultivars. In this study, ten ISSR primers produced a total of 92 bands, 82 of which were polymorphic (representing 89 percent of polymorphism). Jaccard's distances between pairs of accessions were used to define four groups according to their molecular diversity. The results obtained from this study proved the existence of important genetic variability among bean landraces collected at distinct geographical locations, establishing the basis for conservation and utilization of evaluated materials for breeding purposes. ISSR molecular markers were able to genetically differentiate bean accessions despite their expected high genetic homogeneity due to their self-pollinating nature.

\section{Introduction}

The bean crop, together with maize, has been a very important part of the Mexican diet since ancient times. It is now ranked second in terms of cultivated area in Mexico, covering 2.2 million hectares(Zahniser et al., 2010). This crop is cultivated throughout the country at different planting times and under very distinct production systems. A direct consequence of these conditions is the existence of a high genetic diversity that is not just the result of environmental conditions, but also of human-oriented domestication and diversification processes.

However, most cultivars included in the four main bean groups were developed from a relatively narrow genetic base (Bitocchi et al., 2011).

\footnotetext{
*Professor and Researcher, Chapingo Autonomous University, Mexico.

†Professor and Researcher, Chapingo Autonomous University, Mexico.

†Professor and Researcher, Chapingo Autonomous University, Mexico.
} 
Therefore, the existent genetic variability in beans has not been fully exploited, since landraces grown by small producers in Mexican rural areas, the majority of them from indigenous origins, who maintain this diversity, are only sold at local markets (as is the case for local types such as Parraleño, Rebosero, Morado, etc.); therefore, they have been rarely studied and thus their utility for genetic improvement has been limited (Bellon et al., 2009).

Therefore, a common objective for Phaseolus species is to explore the existence of genetic variability in landraces that could enhance genetic diversity of bean seed bank base collections that in turn could be useful for future bean breeding programs (Blair et al., 2012).

To characterize bean genetic diversity, several morphological (Santos et al., 2012), agronomic (Smith et al., 2010), and yield (Beebe et al., 2008) descriptors have been used, along with biochemical (isoenzymes) and molecular markers.

ISSRs molecular markers have proved to be trustful, highly reproducible and easy to develop; in addition, they are able to identify an important number of polymorphisms even in autogamous crops, such as beans, despite their high genetic homogeneity, thereby making them very useful for breeding purposes in these species (Marotti et al., 2007).

Therefore, the main objective of this study was to molecularly characterize 30 bean landraces from distinct geographical origins to explore the existence of genetic variability in order to generate strategies for conservation and potential utilization in future bean breeding programs.

\section{Materials and Methods}

Geographical origins of the 30 accessions considered for this study are detailed in Table 1. Collections were performed during the 70's in the Mexican states of Puebla, Zacatecas, and Oaxaca.

Plantlet production was performed under lab conditions; seeds from each accession were sowed in 200-cavity polystyrene germination trays filled with vermicompost as substrate. When plantlets reached 10 to $15 \mathrm{~cm}$ in height (15 to 20 days after sowing), fresh and healthy leaves were cut for DNA extraction.

DNA extraction. De la Cruz et al. (1997) protocol was used; $0.3 \mathrm{~g}$ of fresh leaf tissue was powder grounded with liquid nitrogen and then transferred to $1.5 \mathrm{~mL}$ plastic tubes preheated to $65^{\circ} \mathrm{C}$ using a thermoblock. Tubes contained $700 \mu \mathrm{L}$ of extraction buffer (Tris-HCl $100 \mathrm{mM}$, EDTA-Na2 $50 \mathrm{mM}, \mathrm{NaCl} 500$ $\mathrm{mM}$, 2-mercaptoetanol $10 \mathrm{mM}$, SDS 1.3\%, $\mathrm{pH} 8.0$ ). Tubes were shaken for homogenization and reheated to $65^{\circ} \mathrm{C}$ for 10 minutes. $200 \mu \mathrm{L}$ of $5 \mathrm{M}$ potassium acetate were added to each tube, ice cooled for 30 to 60 minutes and then centrifuged for 20 minutes at $12,000 \mathrm{xg}$. Supernatant was transferred to new plastic tubes containing $600 \mu \mathrm{L}$ of precooled isopropanol which were kept at $20^{\circ} \mathrm{C}$ for 30 to 60 minutes to precipitate DNA.

Afterwards, the tubes were centrifuged for 5 minutes at $6000 \mathrm{xg}$ and decanted; the DNA pellet was dissolved with $700 \mu \mathrm{L}$ of solution and then $4 \mu \mathrm{L}$ 
of RNase were added. The tubes were incubated at $37^{\circ} \mathrm{C}$ for 1 hour. DNA was reprecipitated using $75 \mu \mathrm{L}$ of $3 \mathrm{M}$ sodium acetate and $500 \mu \mathrm{L}$ of cooled isopropanol for 2 hours. Afterwards, the tubes were centrifuged for 5 minutes at $8000 \mathrm{xg}$, supernatant was discarded and the DNA pellet was washed with 70 $\%$ ethanol. Tubes were again centrifuged for 5 minutes at $8000 \mathrm{xg}$, supernatant was discarded and the DNA pellet was dried at room temperature. Finally, it was dissolved in $50 \mu \mathrm{L}$ of TE and then stored in a refrigerator at $4^{\circ} \mathrm{C}$. Five replications per accession were performed, giving a total of 150 extractions.

Table 1. Geographical Location, Temperature and Elevation Conditions of Collection Sites for 30 Bean Landraces

\begin{tabular}{|c|c|c|c|c|}
\hline No. & Locality & Latitude & Longitude & Altitude \\
\hline 2 & Michac, Pue. & $19^{\circ} 25^{\prime}$ & $98^{\circ} 03^{\prime}$ & 2,320 \\
\hline 5 & Michac, Pue. & $19^{\circ} 25^{\prime}$ & $98^{\circ} 03^{\prime}$ & 2,320 \\
\hline 8 & Michac, Pue. & $19^{\circ} 25^{\prime}$ & $98^{\circ} 03^{\prime}$ & 2,320 \\
\hline 12 & Ixtlahuaca,Pue. & $19^{\circ} 51^{\prime}$ & $98^{\circ} 03^{\prime}$ & 2,250 \\
\hline 20 & Tomatlán, Pue. & $19^{\circ} 53^{\prime}$ & $98^{\circ} 03^{\prime}$ & 2,1300 \\
\hline 49 & S. Nicolás, Pue. & $19^{\circ} 09^{\prime}$ & $97^{\circ} 32^{\prime}$ & 2,380 \\
\hline 54 & Santa Ana, Pue. & $18^{\circ} 50^{\prime}$ & $98^{\circ} 26^{\prime}$ & 1,700 \\
\hline 66 & Tezonteopan, Pue. & $18^{\circ} 44^{\prime}$ & $98^{\circ} 29^{\prime}$ & 1,540 \\
\hline 73 & Xochitlán, Pue. & $18^{\circ} 70^{\prime}$ & $97^{\circ} 77^{\prime}$ & 1,040 \\
\hline 84 & Las Lomas, Pue. & $19^{\circ} 49^{\prime}$ & $97^{\circ} 36^{\prime}$ & 2,140 \\
\hline 93 & Concepción, Zac. & $23^{\circ} 11^{\prime}$ & $102^{\circ} 86^{\prime}$ & 2,215 \\
\hline 97 & Laguna Blanca, Zac. & $23^{\circ} 21^{\prime}$ & $102^{\circ} 04^{\prime}$ & 2,220 \\
\hline 102 & Carrillo, Zac. & $23^{\circ} 20^{\prime}$ & $102^{\circ} 98^{\prime}$ & 2,125 \\
\hline 109 & Fresnillo, Zac. & $23^{\circ} 10^{\prime}$ & $102^{\circ} 98^{\prime}$ & 2,185 \\
\hline 114 & Fresnillo, Zac. & $23^{\circ} 10^{\prime}$ & $102^{\circ} 98^{\prime}$ & 2,185 \\
\hline 124 & Apozol, Zac. & $21^{\circ} 26^{\prime}$ & $102^{\circ} 59^{\prime}$ & 1,300 \\
\hline 127 & Apozol, Zac. & $21^{\circ} 26^{\prime}$ & $102^{\circ} 59^{\prime}$ & 1,300 \\
\hline 130 & Apozol, Zac. & $21^{\circ} 26^{\prime}$ & $102^{\circ} 59^{\prime}$ & 1,300 \\
\hline 140 & Apozol, Zac. & $21^{\circ} 26^{\prime}$ & $102^{\circ} 59^{\prime}$ & 1,300 \\
\hline 168 & Concepción, Zac. & $23^{\circ} 11^{\prime}$ & $102^{\circ} 86^{\prime}$ & 2,215 \\
\hline 179 & Ocotlán, Oax. & $16^{\circ} 47^{\prime}$ & $96^{\circ} 40^{\prime}$ & 1,500 \\
\hline 188 & Tlapacoyan, Oax. & $19^{\circ} 44^{\prime}$ & $96^{\circ} 50^{\prime}$ & 1,460 \\
\hline 197 & Tlacolula, Oax. & $16^{\circ} 57^{\prime}$ & $96^{\circ} 28^{\prime}$ & 1,600 \\
\hline 208 & Miahuatlán, Oax. & $16^{\circ} 19^{\prime}$ & $96^{\circ} 35^{\prime}$ & 1,558 \\
\hline 212 & Miahuatlán, Oax. & $16^{\circ} 19^{\prime}$ & $96^{\circ} 35^{\prime}$ & 1,558 \\
\hline 218 & Miahuatlán, Oax. & $16^{\circ} 19^{\prime}$ & $96^{\circ} 35^{\prime}$ & 1,558 \\
\hline 230 & Ayoquezco, Oax. & $16^{\circ} 41^{\prime}$ & $96^{\circ} 50^{\prime}$ & 1,448 \\
\hline 238 & Ayoquezco, Oax. & $16^{\circ} 41^{\prime}$ & $96^{\circ} 50^{\prime}$ & 1,448 \\
\hline 244 & Zimatlán, Oax. & $16^{\circ} 52^{\prime}$ & $96^{\circ} 47^{\prime}$ & 1,500 \\
\hline 248 & Villa de Etla, Oax. & $17^{\circ} 12^{\prime}$ & $96^{\circ} 48^{\prime}$ & 1,660 \\
\hline
\end{tabular}

DNA quantification and quality evaluation. DNA concentration for the different samples was determined using a NanoDrop 1000 Spectrophotometer (Thermo Scientific Wilmington, USA) and dilutions were made in order to get a uniform concentration of $10 \mathrm{ng} \mu \mathrm{L}^{-1}$. Later the five replications per accession were mixed to make one bulk per genotype. 
DNA quality was assessed running a $8 \%$ agarose gel using $100 \mathrm{~mL}$ of TAE $1 \mathrm{X}$ buffer (Tris base $40 \mathrm{mM}, \mathrm{pH} 7.8$; sodium acetate $20 \mathrm{mM}$ and EDTA 2 $\mathrm{mM}, \mathrm{pH} 8.0)$. Over a parafilm tape, $2 \mu \mathrm{L}$ of load buffer $(0.2 \%$ blue bromophenol, 0.2 xylene cianol, $25 \%$ glycerol, $5 \mathrm{mM}$ EDTA, $50 \mathrm{mM}$ Tris$\mathrm{HCl}, \mathrm{pH}$ 8.0) were mixed with $10 \mu \mathrm{L}$ from each sample, while in both extremes $3 \mu \mathrm{L}$ of $1 \mathrm{~Kb}$ molecular ladder were loaded. Electrophoresis was performed at 90 volts for 1.5 hours. Afterwards, the gel was removed and dyed using an ethidium bromide solution $(0.6 \mu \mathrm{g} \cdot \mu \mathrm{L}$ in TAE $1 \mathrm{X})$ for 20 minutes. Subsequently, the gel was drained and put inside a UV transilluminator to be photographed using a Kodak EDAS 290 camera.

ISSR molecular profiles. 21 Sigma ${ }^{\circledR}$ primers were originally screened to evaluate their ability to produce clear and reproducible amplification products. From them only 10 primers were finally selected. The PCR protocol was as follows: $2.5 \mu \mathrm{L}$ of DNA (10 $\left.\mathrm{ng} \mu \mathrm{L}^{-1}\right)$ were collocated into $1.5 \mathrm{~mL}$ plastic tubes containing $22.5 \mu \mathrm{L}$ of reaction mixture integrated by PCR buffer $(2.5 \mu \mathrm{L} 10 \mathrm{X})$, Taq DNA polymerase $\left(0.3 \mu \mathrm{L}\right.$, Invitrogen $\left.{ }^{\circledR}\right)$, DNTP's $(10 \mu \mathrm{L} 500 \mu \mathrm{M}), \mathrm{MgCl}_{2}$ $(3 \mu \mathrm{L} 50 \mathrm{mM})$, primer $(1.5 \mu \mathrm{L} 10 \mathrm{ng} / \mu \mathrm{L})$ and water $(5.2 \mu \mathrm{L})$ to complete a 25 $\mu \mathrm{L}$ total volume. The tubes were incubated in a Techne TC-412 thermocycler using the following program: one pre-denaturation cycle of 20 minutes at $93^{0}$ $\mathrm{C}, 40$ denaturation cycles (one minute at $93^{\circ} \mathrm{C}$ each), alignment (one minute at $36^{\circ} \mathrm{C}$ ), extension (one minute at $72^{\circ} \mathrm{C}$ ), and one final extension cycle at $72^{\circ} \mathrm{C}$. The amplification products were separated by electrophoresis in agarose gels, which were later stained with ethidium bromide, developed inside the UV transilluminator and photographed using a Kodak EDAS 290 camera.

Statistical analysis. The similarities and genetic differences between pairs of accessions were computed from band patterns allocating the 0 value to the absence and a value of 1 to the presence of each band. Amplification products were recorded for each primer, and a consecutive number was assigned to them according to their migration distance in the agarose gel. The registration of ISSR patterns obtained from each of the 10 selected primers for the 30 accessions created the basic data matrix (BDM).

To evaluate the discrimination power of tested primers, a descriptive analysis of amplified products was obtained. Then quantitative variables such as a number of amplified bands, the proportion of mono and polymorphic loci, and polymorphic information content per primer were quantified using InfoGen® software (ver. 2011, Universidad de Córdoba, Argentina). Because genetic distance can be used to compare similarity among different accessions, groups were constructed under the criteria of Ward's minimum variance using Jaccard's distance $(1-\mathrm{s})$ to construct a dendrogram. The cut distance was estimated by Hotelling's $\mathrm{T}^{2}$ pseudostatistic (Taylor, 2010), using PROC CLUSTER and PROC TREE from SAS® Ver 9.0. 


\section{Results and Discussion}

Table 2 shows the sequences and annealing temperatures of the ten primers used to obtain the molecular profiles of the studied accessions. A total of 92 bands were obtained, 10 of them monomorphic, thereby representing a total percentage of polymorphism of 89 percent. These results diverged from those obtained by González et al. (2005), who using four primers obtained only 40 percent of polymorphism, half of that obtained in this study. This noticeable difference could have been due to the fact that the evaluated landraces came from small communities located in distinct agricultural regions and had been maintained in situ according to local consumption preferences, and thus significant genetic differences among accessions are to be expected (Bellon et al., 2009).

Table 2. Primers, 5'-3' Sequence, Annealing Temperature (AT), Number of Polymorphic Bands (PB), Monomorphic Bands (MB), Total Bands (TB), Proportion of Polymorphic Loci (PPL), Polymorphic Information Content (PIC), Standard Error (SE), Percentage of Amplification (PA), and Probability for Two Individuals to Share the same Allele by Chance (PSSA) of ISSR Fingerprints from 30 Bean Landraces

\begin{tabular}{ccccccccccc}
\hline Name & $\begin{array}{c}\left(\mathbf{5}^{\prime}-\mathbf{3}^{\prime}\right) \\
\text { Sequence }\end{array}$ & AT & PB & MB & TB & PPL(95) & PIC & SE & PA & PSSA \\
\hline LOL2 & $(\mathrm{CT})_{8} \mathrm{GC}$ & 68 & 8 & 0 & 8 & 0.88 & 0.17 & 0.02 & 58.33 & $6.4 \mathrm{E}-06$ \\
LOL7 & $(\mathrm{GAGA})_{3} \mathrm{CC}$ & 53 & 9 & 3 & 12 & 0.33 & 0.13 & 0.03 & 39.17 & $6.9 \mathrm{E}-03$ \\
LOL8 & $(\mathrm{GT})_{6} \mathrm{CC}$ & 58 & 11 & 0 & 11 & 1.00 & 0.31 & 0.02 & 51.21 & $1.7 \mathrm{E}-13$ \\
LOL9 & $(\mathrm{CCA})_{3} \mathrm{GC}$ & 58 & 10 & 0 & 10 & 1.00 & 0.25 & 0.02 & 57.67 & $5.8 \mathrm{E}-09$ \\
LOL10 & $(\mathrm{GAG})_{3} \mathrm{GC}$ & 56 & 10 & 0 & 10 & 1.00 & 0.29 & 0.02 & 70.00 & $1.6 \mathrm{E}-10$ \\
LOL12 & $(\mathrm{GTG})_{3} \mathrm{GC}$ & 61 & 5 & 4 & 9 & 0.56 & 0.17 & 0.04 & 71.85 & $2.7 \mathrm{E}-03$ \\
ISSR02 & $(\mathrm{CA})_{8} \mathrm{AAGG}$ & 69 & 7 & 0 & 7 & 1.00 & 0.32 & 0.01 & 50.95 & $2.2 \mathrm{E}-21$ \\
PHV06 & $\mathrm{CCA}(\mathrm{CT})_{8}$ & 58 & 10 & 0 & 10 & 1.00 & 0.18 & 0.04 & 82.67 & $1.9 \mathrm{E}-07$ \\
PHV07 & $\mathrm{GTG}(\mathrm{GT})_{8}$ & 57 & 8 & 2 & 10 & 0.30 & 0.11 & 0.03 & 64.37 & $2.3 \mathrm{E}-03$ \\
UBC867 & $(\mathrm{AGC})_{6}$ & 62 & 4 & 1 & 5 & 0.40 & 0.12 & 0.01 & 63.33 & $4.0 \mathrm{E}-03$ \\
\hline Total & & & 82 & 10 & 92 & & & & 60.54 & $7.1 \mathrm{E}-74$ \\
\hline
\end{tabular}

Regarding primer description, an average of 8.2 bands per primer was obtained. LOL7 and LOL8 primers produced the highest number of amplified bands (12 and 11, respectively). However, higher polymorphic information content was observed for ISSR02, LOL8 and LOL10, making them the most informative and thus the ones to be recommended for subsequent studies on bean molecular characterization. The obtained results agree with those achieved by Marotti et al. (2007), who found that LOL8 produced exclusive bands that could be used as specific markers to molecularly differentiate bean populations.

The lowest probability for two individuals to share the same allele by chance (PDICMA) was also observed for ISSR02 primer, followed by LOL8 
Vol. 1, No. 3 Ortega et al.: Exploration of Genetic Variability of Bean ...

and LOL10. Therefore, these additional results corroborate the usefulness of these primers for population distinction.

\section{Genetic Relationships among Accessions}

From the genetic fingerprintings attained for the 30 evaluated landraces, genetic distances between pairs of accessions were estimated using Jaccard's similarity coefficient $(S)$ transformed to genetic distance $(1-S)$. Then a cluster analysis was performed using Ward's minimum variance criterion. The robustness of the obtained dendrogram was corroborated by 1,000 resampling using the bootstrapping method. The final dendrogam is presented in Figure 1.

Figure 1. Dendrogram Generated from Jaccard's Distances (1-S) for 30 Bean Landraces

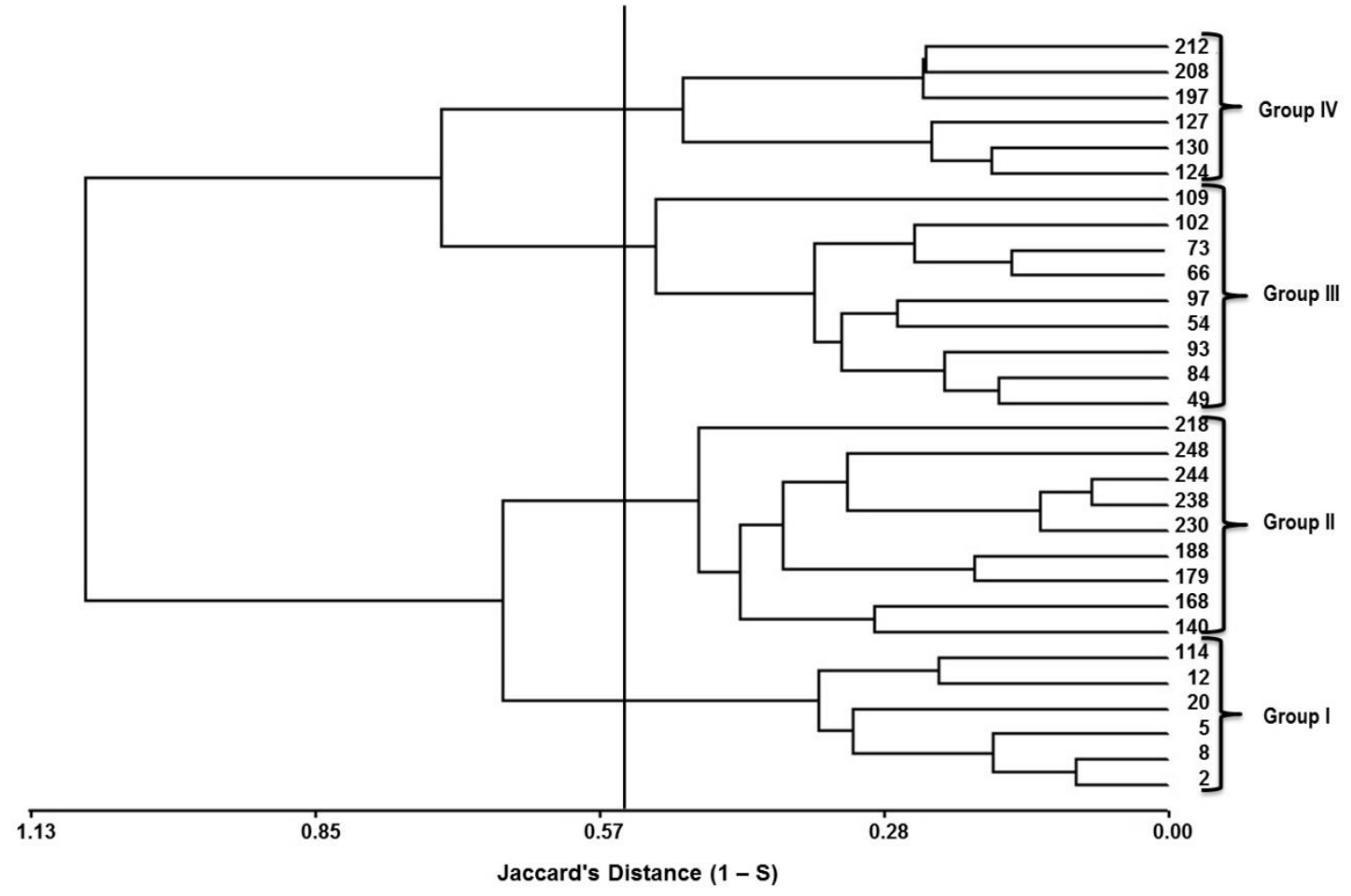

Dendrogram cut distance (0.49) was defined using Hotelling's $\mathrm{T}^{2}$ pseudostatistic (first value lower than the 20 percent of the total evaluated accessions, which in this study corresponded to a value of 6). This defined four different groups.

Figure 1 shows that 238 and 244 accessions, both collected in different small communities located $12 \mathrm{~km}$ apart in Oaxaca, were the most similar genetically with a distance value of 0.08 . While accessions 109 and 248 were the most distant ones ( 0.51 genetic distance), the first one was collected in Fresnillo, Zacatecas, while the second one came from Villa de Etla, Oaxaca, 
located more than $900 \mathrm{~km}$ away. It should be noted that accession 248 turned out to be a commercial black bean variety known as 'Jamapa'. This result confirms that the landraces evaluated in this study in fact represent molecular profiles quite distinct to those of improved varieties; therefore, they could be useful sources of novel genetic variability that has not been exploited until now (Bellon et al,. 2009).

Group I was formed by 6 accessions, 5 of them collected in distinct localities in Puebla and one in Zacatecas. These results suggest the existence of genetic similarities among landraces despite their different geographical origin. These similarities could be linked to the fact that all these landraces have "butter" seed color, with the exception of accession 20, which corresponds to "little cow" type. Two of the most related accessions (2 and $8, \mathrm{JD}=0.09$ ) belonged to this group, both collected at the Michac location.

Group II contained 9 accessions, two of them (140 and 168) from Zacatecas and therefore with clear-colored seeds grouped together with a genetic distance of 0.29 , while the other seven accessions, all of them from Oaxaca, presented thin black seeds. Considering the genetic variation detected in this state, it can be seen that accessions 238 and 244, collected at locations $13 \mathrm{~km}$ apart, were the most closely related. Similarly, accessions 230 and 238, both collected at the same location, grouped together with a distance of 0.08 .

Group III was also formed by 9 accessions, five of them collected at localities in Puebla and four in Zacatecas. Two of the most related accessions within this group were 49 and $84(\mathrm{JD}=0.17)$, both with black seeds collected at two different locations $45 \mathrm{~km}$ apart. On the other hand, accessions 93, 97, 102 , and 109, all of them with clear seeds, came from different locations in Zacatecas. Finally, Group IV was formed by three landraces of 'Castilla pink' seeds, all of them from localities in Zacatecas (accessions 124, 130 and 127), whereas accessions 197, 208 and 212, all of them from Oaxaca and with thin black seeds, grouped together.

The results obtained in this study suggest that similarities among the molecular profiles of the evaluated accessions were in part associated with seed color, despite the fact that some of the landraces sharing the same seed color came from very distant locations. These results agree with those found by Sadeghi and Cheghamirza (2012), who worked with 21 bean varieties and formed groups with similar seed colors, which was attributed to the high potential of ISSR markers to evaluate genetic diversity among materials and thus their usefulness in guiding possible crosses to be performed in a breeding program.

The results of this study confirm the existence of genetic variability among the 30 collected materials since all of them showed different molecular profiles, which in turn suggests the desirability of keeping all the accessions since they represent distinct sources of genetic diversity that could be useful in the future (Blair et al., 2012).

The next step in the characterization process of this bean germplasm should be a morphological and agronomical characterization of the evaluated materials, in order to verify that they possess useful agronomical traits such as 
precocity, growth habit, good yield, seed quality, insect and disease resistance, etc., that could be transferred by crossing bean commercial varieties (Kelly, 2010).

\section{Conclusions}

The records obtained in this study make it possible to establish the basis to generate use and conservation strategies for the evaluated bean landraces. There is genetic variability among bean genotypes from different geographical locations. ISSR markers were effective in genetically distinguishing the evaluated materials despite their expected high homozygosity due to the autogamous nature of this crop.

\section{References}

Beebe, S.E.; Rao, I.M.; Cajiao, C.; Grajales, M. 2008. Selection for drought resistance in common bean also improves yield in phosphorus limited and favorable environments. Crop Science 48: 582-592.

Bellon, M.R.; Barrientos-Priego, A.F.; Colunga-GarcíaMarín, P.; Perales, H.; Reyes A., J.A.; Rosales A., R.; Zizumbo-Villarreal, D. 2009. Diversidad y conservación de recursos genéticos en plantas cultivadas. En: Capital NaturSingh, 2001)al de México Vol. II: Estado de Conservación y Tendencias de Cambio. CONABIO, México, pp. 355-382.

Bitocchi, E.; Nanni, L.; Belucci, E.; Rocci, M.; Giardini, A.; Spagnoletti, P.; Logozzo, G.; Stougaard, J.; McClean, P.; Attene, G.; Papa, R. 2011. Mesoamerican origin of the common bean (Phaseolus vulgaris L.) is revealed by sequence data. PNAS 109(14):788-796.

Blair, M.W.; Soler, A.; Cortés, A.J. 2012. Diversification and population structure in common beans (Phaseolus vulgaris L.). PLoS ONE 7(11): e49488. doi:10.1371/journal.pone.0049488.

De La Cruz, M.; Ramírez, F.; Hernández, H. 1997. DNA isolation and amplification from cacti. Plant Molecular Biology Reporter 15: 319-325.

González, A.; Wong, A.; Delgado, A.; Papa, R.; Gepts, P. 2005. Assessment of inter simple sequence repeat markers to differentiate sympatric wild and domesticated populations of common bean. Crop Science 45:606-615.

Kelly, J.D. 2010. The Story of Bean Breeding. Michigan State University (Ed.). U.S.A. 30 pp.

Marotti, I.; Bonetti, A.; Minelli, M; Catizone, P.; Dinelli, G. 2007. Characterization of some Italian common bean (Phaseolus vulgaris L.) landraces by RAPD, semirandom and ISSR molecular markers. Genetic Resources and Crop Evolution 154(2):175-188.

Sadeghi, A.; Chegharmirza, K. 2012. Efficiency of RAPD and ISSR marker systems for studying genetic diversity in common bean (Phaseolus vulgaris L.) cultivars. Annals of Biological Research 3: 3267-3273.

Santos de L., M.; De Souza C., J.E.; Souza C., P.D.; Santana P., C.; Faria V.; R.; Cecon, P.R. 2012. Characterization of genetic variability among common bean genotypes by morphological descriptors. Crop Breed. Apl. Biotech. 12(1):76-84. 
Smith, T.H.; Michaels, T.E.; Pauls, K.P. 2010. OAC Derkeller common bean. Canadian J. Plant Sci. 90:715-717.

Taylor, M.E. 2010. A Possible Application of Hotelling's T2? Statistic in Employment Discrimination Proceedings. Cornell University, USA. 22 p.

Zahniser, S.; Ver T., M.; Cuéllar A., J.A.; López L., N.F.; Bhatta, R. 2010. The U.S. and Mexican dry bean sectors. USDA Report VGS-341-01. 41 pp. 
